\title{
A NEW PLAN FOR THE PRIVATE FINANCING OF DELINQUENT TAX PAYMENTS
}

\author{
Paul Studenski*
}

The municipalities of this country are slowly emerging from the financial difficulties in which they found themselves during the worst years of the depression. These difficulties have been due preeminently to three causes.

x. The severe drop in tax collections resulting from the inability of property owners, with incomes severely reduced by the depression, to pay their taxes on time.

2. The collapse of the money market during the first years of the depression and the inability of municipalities to obtain loans in anticipation of the collection of their taxes.

3. The fact that at the beginning of the depression there were outstanding against the municipalities large amounts of loans contracted by them against tax arrears, and that these loans have been maturing for payment.

The difficulties of the municipalities, in other words, have been due in no small measure ( $I$ ) to the maintenance by them of defective systems of tax collection, under which large amounts of tax arrears were accumulating even during prosperous times, (2) to the prevalence of a tendency among them to borrow indiscriminately against all tax arrears without regard to their collectibility, and (3) to the common failure on their part to set up reserves against uncollectible taxes.

\section{The Difficulties Confronting the Municipalities and Their Taxpayers under the Present System of Tax Collection}

No municipality in this country collects all its taxes at the time they become due. There are always some taxpayers who fall behind in their payments. No small part of this delinquency is due to the fact that taxes are collected in a lump sum annually or semi-annually. The taxpayer usually accumulates from his monthly rents or income the amount required for his taxes. If he fails to do so, or if, after having accumulated the money, he spends it for some other purpose, he is often unable to make this lump-sum payment.

- Ph.D., 1921, Columbia University. Professor of Economies, New York University, New York City. Consultant to various federal, state and municipal authorities. Vice-President of the Tax Kesearch Foundation. Author of Teachers' Pensions (1921), Public Borrowing (1930), Government of Metropolitan Areas (1931), Chapters in Public Finance (1932 and 1934), and various monographs and reports. Editor of Current Problems in Public Finance (1933), Government Finance in the Modern Economy (1936), Taxation and Public Policy (1936), and the section on comparative tax legislation and tax statistics in Tax Systems of the World. Contributor to the Encyclopaedia of the Social Sciences and otber publications. 
In most instances such taxpayers cannot obtain loans from banks for the payment of their taxes. Since loans of this nature are a subordinate claim against the taxpayer's property, they are not considered by the banks to be a good risk. Only where the personal credit of the taxpayer with the bank is especially good or where the bank happens to be a mortgagee of the property will the bank lend money to the taxpayer for the payment of taxes. In the latter case, the bank can add the loan to the amount of the mortgage, thus making the loan nearly as secure as the original mortgage.

It may take a delinquent taxpayer several months to accumulate the money with which to liquidate his arrears and the penalties thereon. By the time the taxpayer pays these arrears, however, another tax payment often becomes due and thus he is forced again to default. Delinquency tends to become recurrent or perpetual. Taxes are increased through penalties sometimes twenty per cent, or more.

The finances of a municipality are affected adversely through borrowing when the municipality fails to collect all the taxes at the time when they become due. It is true that the municipality eventually will collect nearly all the taxes it has levied. Taxes are ultimately paid because of

I. The heavy penalties for delinquency which, for example, amount to ten per cent per annum in New York City, and run as high as eighteen per cent in some places in the State of New York, and

2. The fact that the municipality may exercise its right of selling the tax lien against the property or even the property itself to any private bidder.

In New York City, for example, ordinarily only a little over one per cent of taxes are still uncollected after the expiration of three years and are then offered as tax liens for sale. Less than one per cent of the levy becomes uncollectible and has to be written off the city's books. While taxes are in arrears, however, it becomes necessary for the municipality to make up somehow for the shortage in its revenue. Ordinarily, it does that by borrowing from the banks.

By thus allowing the taxpayers time within which to pay the taxes (three years in New York City, as already noted) before resorting to the drastic measure of a tax sale, and by borrowing from the banks against tax arrears, the municipality really extends credit to the taxpayers, while it itself borrows the necessary cash from the banks. It must repay its loans promptly, even though it may not collect the taxpayers' debts during the term of the loan. Political considerations may compel the municipality to be lenient with its tax debtors, even though it may not be able to obtain this same degree of leniency from the financial institutions that extend credit to it against its tax arrears. This system of financing tax arrears has substantial disadvantages from the city's point of view.

The disadvantages from the city's point of view become especially apparent in times of a depression when tax arrears increase and when the money market tightens. The municipality is compelled at such times to extend credit to many more taxpayers and it must do so in each case for a much longer time than in ordinary times. Yet, 
it cannot obtain as much credit in the money market as it did when money was freer and when its tax collections were good. Municipal credit is founded, in the last analysis, upon the ability of the taxpayers to make prompt payments. If taxes are not paid promptly, municipal credit grows weak. Under such conditions, loans cannot be obtained and tax arrears cannot be converted into cash. Both taxpayers and the municipality suffer under this arrangement. Under this awkward system, the municipality endeavors to finance the taxpayers from whom its own funds are supposed to be derived, and becomes involved in a vicious circle. It is unable to convert its tax arrears into cash because of the weakness of its credit, and conversely, it suffers from a weakness of credit because of its inability to convert its tax arrears into cash.

\section{The New Tax Finance Plan for the Establishment of a Special Type of Credit Instrument and Credit Institution for the Benefit of the Taxpayers}

The necessity for the extension of credit to taxpayers by municipalities would be eliminated, and the credit of the municipalities would be greatly strengthened if the taxpayers themselves were enabled to borrow funds for the payment of their taxes from private sources. This may be accomplished ( $\mathrm{r}$ ) by the establishment of a new type of private credit institution for the accommodation of these taxpayers; and (2) by the creation of a new form of commercial or mortgage paper, indirectly founded upon the tax lien as it exists under the present law.

A plan of this sort was evolved by Mr. B. G. Orlove, Jr. of New York City and is embodied in Chapter 345 of the Laws of New York of $1935 .^{1}$ Steps are under way to bring about its effectuation in New York City. The proposal involves the establishment of one or more private finance corporations to lend funds for tax payments under the provisions of the aforementioned law.

The purpose of such a lending corporation will be limited by charter to the advancement of funds to property owners or parties having an interest in property for delinquent and for current taxes. Normally loans may be extended by this'lending corporation to taxpayers for periods of twelve months. These loans may be made payable by means of twelve notes of equal amount maturing monthly. The. lending corporation will be limited in its charges to four per cent interest per annum on the unpaid balances and to a service charge of two per cent of the amount of the loan. It is provided, however, that after default, the legal rate of six per cent may be charged on sums actually in default.

On a year's loan of $\$ 12,000$ for tax arrearages payable in monthly instalments the charges would amount to $\$ 260$ in interest and $\$ 240$ in service charges. On a year's

\footnotetext{
${ }^{2}$ The plan was elaborated on the legal side by Abraham J. Isserman of the New Jersey Bar. The author of this article collaborated in the formulation of the plan, the New York State Tax Commission and New York City Department of Finance rendered material assistance in furthering it. The text of the law incorporating the main features of the plan is appended. See p. 369 , infra.
} 
loan of $\$ 12,000$ granted under the same terms for the payment of current taxes the charges for interest and service would total only $\$ 320$, because the charges would be reduced by the four per cent discount allowed by the city for advance payment of the second semi-annual instalment of the tax. In this case the city would benefit by obtaining the full year's taxes at the time the first instalment is due. The taxpayer would benefit by actually spreading his payments over the entire year.

To assure repayment of the loan extended by the lending corporation to the taxpayer, the corporation would receive an interest in the tax lien which the city is holding against the property. A very simple way of providing this security would be to empower the municipal corporation to accept payment from the lending corporation upon request from the taxpayer. The municipal corporation would be empowered to acknowledge payment by means of a special receipt to be known as a "conditional tax receipt."

The essence of this "conditional tax receipt," is that the tax lien remains in force until the "conditional tax receipt" is surrendered to the city tax collector for cancellation. Upon surrender and cancellation of the "conditional tax receipt" the municipality will issue the final receipted tax bill, extinguishing the tax lien against the property for the amount and period covered in the cancelled "conditional tax receipt."

The default by the borrower to the lending corporation does not change the status of the tax lien in any way. The procedure now provided for by law for the sale of tax liens or properties for non-payment of taxes, will in all cases remain unchanged as if the "conditional tax receipt" had not been issued. However, a municipality availing itself of the plan may hold no such sale in the case of taxes covered by a conditional receipt, before expiration of one year from date of the issuance of such conditional receipt, nor later than three years from such date. For the purposes of this sale the existence of a "conditional tax receipt" outstanding against the property will not be deemed payment of the taxes.

Out of the proceeds of the tax lien sale, however, the municipal corporation is required to pay to the lending corporation, upon the surrender of the "conditional tax receipt," the amount actually due to the lending corporation on its loan contract with the borrower. The municipality retains for its own uses any excess over that amount.

The "conditional tax receipt" received from the municipality must be deposited by the lending corporation with a banking institution as trustee. The trustee will collect for the account of the lending corporation the payments due on the loan contract and credit such payments on the "conditional tax receipt."

The books of the lending corporation will be subject to examination by duly accredited auditors of any municipality which has issued "conditional tax receipts" to it. The municipal corporations are authorized to make further regulations for the protection of the taxpayers who may finance their tax bills through this plan. 


\section{The Advantages of the New Plan}

The paper created by the lending corporation will have great liquidity, security, and marketability. It will have these qualities ( $\mathrm{r}$ ) because of the regular monthly payments of the loans it represents; (2) because its actual underlying security is an unliquidated tax lien, which is a claim prior to any existing or future mortgages; and (3) because the loans it represents will ordinarily constitute only $2 \frac{1}{2}$ to 5 per cent of the value of the property against which it is issued.

The paper is a first lien against real estate; therefore it will be an eligible investment for savings banks, insurance companies and trust funds. When endorsed by the lending corporation it will be a desirable investment for commercial banks and also for dealers in bankers' acceptances and commercial notes.

Inasmuch as there is available now, as a result of the business depression, a great excess of cash in banks for credit expansion, and, inasmuch as the federal government is using every means at its disposal to induce the banks to make these reserves available for the extension of legitimate credits, there will be no difficulty in finding a market for this paper. The banks and other institutions should eagerly take up the taxpayers' notes endorsed by the lending corporation with "conditional tax receipts" attached thereto. They should also liberally buy of the lending corporation's direct obligations which will be secured by the taxpayers' notes ("conditional tax receipts" attached) and by the assets of the corporation. It is high time that a paper be offered to the market that would possess the security with which even the most discriminating investor would not be able to find fault.

The appearance of this prime paper at this time would be especially propitious as it would convert a certain class of troublesome debts and inactive assets into live, circulating media. It would give employment to funds now lying idle in banks and direct their flow into the coffers of the municipalities where they may be used for public good.

The plan proposed here would permit an almost complete elimination of delinquencies in the payment of taxes and would supply the municipality with nearly all the taxes at the time when they become due. The municipality would then be in an excellent position to demand a full payment of the tax inasmuch as the taxpayer would have no legitimate excuse for not paying his tax. He would always be in a position to obtain financing for his tax bill. The only exceptions would occur in those rare cases in which the amount of taxes and arrears closely approach the market value of the property.

Manifestly, if the tax levies would be made sufficient to cover the municipality's expenditures and, if at the same time, the tax collections of the municipality would be improved as envisaged by the Orlove plan, the municipality's credit would be greatly enhanced. The municipality would be able to borrow large amounts for capital outlays at low rates of interest, at a time when these outlays can be made advantageously and economically. This would help the revival of business. There 
would also be an incidental gain to the thousands of holders of municipal bonds (both individuals and institutions) through the improved marketability and appreciation in the price of the municipality's obligations.

The taxpayer would gain through the convenience of monthly payments of his taxes, through the avoidance of the penalty of ro per cent or more because of tax delinquency, by the fact that his tax debt has been funded, and by the fact that the conditional payment of his tax will generally be regarded by the mortgagees as a mere technical default. As long as the taxpayer promptly meets his payments to the lending corporation, thus automatically liquidating the taxes against his property, the mortgagee will be satisfied.

The introduction recently in several states of the system of quarterly collection of taxes will undoubtedly reduce somewhat tax delinquency and to that extent may diminish the need for the adoption of this plan. But it will not eliminate the need for it altogether. So long as tax delinquencies occur, the need for such a plan of financing them will continue.

To summarize, the benefits of the plan to the various parties would be as follows:

r. To the municipality:

(a) the immediate conversion of its frozen tax arrears into cash without any cost to it;

(b) a considerably improved liquidity of its income;

(c) an improvement in its credit standing.

2. To the taxpayers:

(a) substitution of instalment payments for payments in lump sums;

(b) avoidance of penalties of ten per cent or more for delinquency;

(c) relative protection against foreclosure because of tax default.

3. To the mortgagees:

the orderly and easy liquidation by the property owner of a prior lien against the mortgages with the avoidance of heavy penalty accruals.

4. To the holders of municipal obligations:

the appreciation in the price of bonds and the improvement in their marketability.

5. To the country at large:

the creation of a new credit investment and the utilization of a part of the unused credit resources of the country for a new and productive purpose.

\section{Reforms With Which the Tax Finance Plan Is Linked}

State and municipalities desiring to avail themselves of the tax finance plan will find it also necessary so to reorganize their procedures for the collection of taxes and disposition of tax liens as to insure to the purchasers of tax liens clear titles and a fair, effective, and inexpensive procedure of lien foreclosure. Otherwise the liens will not be purchased, delinquencies will remain unliquidated, and it will not be safe for lending companies to extend the desired facilities in these jurisdictions.

In the second place, it will be necessary for such states and municipalities to set up adequate reserves against uncollectible taxes, if they have not already done so. 
It will be necessary for them to do it in order that their collections may equal their cash requirements and also that the lending companies may safely lend money to their taxpayers.

Since the uncollectible taxes are represented really by the tax liens which can not be converted into cash because there are no purchasers for them, the amounts which the city should appropriate each year to the reserves may be measured by the amounts of tax liens remaining undisposed each year. In other words, the appropriation may be fixed at the amount of tax liens offered for sale during the preceding year, but remaining undisposed at the end of the year, less the amount of the tax liens offered for sale during previous years but disposed of only during the preceding year. If a municipality makes such appropriations and raises the amounts of its tax levies correspondingly, it will be collecting enough money annually to meet its current budgetary requirements and will be operating on a cash basis.

A municipality maintaining such a reserve against uncollectible taxes as described, would be able in bidding in tax liens remaining unsold, actually to transfer cash from the reserve fund to the general fund, thus making the cash available for current expenditures and covering the deficits in its current tax collections. Whereever a conditional tax receipt is outstanding against a tax lien so bid in by the municipality, the municipality would have to reimburse the lending company holding such a receipt for the amount owed to it thereupon by the taxpayer, since the municipality had received from the lending company originally the full amount of the tax. Otherwise the municipality would be getting both the tax and the property, and would be appropriating to itself the money belonging to the company.

Where the penalties collected on delinquent taxes and the discounts allowed for the prepayment of taxes are substantial, they should be taken into account in the determination of the amount to be appropriated to the reserves. The penalties collected during the preceding year should be deducted from the amount otherwise required to be appropriated, since they represent a gain in revenue. The discounts allowed during the preceding year should be deducted from such amount, since they represent a loss in revenue.

A reserve constituted in this manner would be the least that a municipality desiring to be solvent would have to maintain. It will take care of the annual deficits in tax collections. But it will not take care of the accumulated deficits therein. To take care of them a more substantial reserve amounting to, say, 25 or 30 per cent of the tax levy would have to be created. Such a reserve may be accumulated over a period of, say, 15 years with the aid of a special annual appropriation of $1 \frac{1}{2}$ or 2 per cent of the levy. The reserve should be invested in the short term paper issued by the city in anticipation of the collection of taxes and liquidation of tax liens so that it would no longer be necessary for the city to borrow in the money market the funds represented by the accumulated tax delinquency.

Finally, to complete the reform of its system of tax collection, a municipality 
should also synchronize its tax collection dates and expenditure periods. It should reduce and, eventually, do away completely with, its recurrent tax anticipation borrowing. How this may be accomplished is a separate problem which need not be discussed here. ${ }^{2}$

Thus, th: Orlove tax finance plan is intimately linked up with a whole set of measures for the improvement of tax collections. It occupies a distinct place in a program of reform of municipal finance.

\section{APPENDIX}

New York LAws, 1935, ChaptrR 345

AN ACT to amend the tax law, in relation to the issuance of conditional tax receipts

The People of the State of New York, represented in Senate and Assembly, do enact as follows:

Section r. Sections ninety-seven, ninety-seven-a, ninety-seven-b, ninety-seven-c and ninety-seven-d of chapter sixty-two of the laws of nineteen hundred nine, entitled "An act in relation to taxation, constituting chapter sixty of the consolidated laws," as added by chapter five hundred and ninety-six of the laws of nineteen hundred thirty-four, is hereby amended to read as follows:

\$97. Payments of taxes from loan corporations. Any municipal corporation may as hereinafter provided accept payment for taxes on real estate, water rates or special assessments from any corporation organized under the laws of the state of New York for the purpose of extending loans to taxpayers for the payment of taxes and may as hereinafter provided issue therefor a conditional tax receipt. Such payment shall be conditionally credited by the municipal corporation against the taxes due on the specific property for which payment is made, but shall not extinguish the tax lien existing against said property by reason of said taxes, until the conditional tax receipt endorsed as paid is surrendered for cancellation to the municipal corporation. Such payments may be used by the municipal corporation in the same manner as if they were made by the taxpayer directly.

\$97-a. Limitations. Municipal corporations may accept such payments from corporations extending loans for such purpose provided that such lending corporation shall have a minimum paid up capital of at least one million dollars and shall charge not more than four per centum interest on unpaid balances on moneys loaned, nor more than two per centum of the amount of the loan as a service charge for making said loan; provided, however, that in the event of a default in the payment of such a loan the lending corporation may charge six per centum interest per annum on all sums in default; and provided furthermore, that the lending corporation shall deposit the conditional tax receipt within three days after receiving the same with a banking institution, trust company, state bank, national bank, or federal reserve bank of the district in which the municipal corporation is located.

597-b. Deposit and delivery of conditional tax receipts. Immediately upon the execution of the loan contract between the borrowing taxpayer and the lending corporation the said lending corporation shall pay to the municipal corporation the moneys provided for therein. The borrowing taxpayer shall make payments on said loan to the banking institution with which the conditional tax receipt shall have been deposited for the account of the lending corporation. Such payments when made shall be entered and acknowledged

'See the author's article, Temporary Borrowings in Anticipation of Tux Collections (May, 1933) Tax Courracrer (organ of the National Association of Municipal Financial Offeers). 
by the banking institution upon the conditional tax receipt, and said conditional tax receipt shall remain in the possession of the said banking institution until the loan is fully discharged, or until there occurs a default. In the event the loan is fully discharged the conditional tax receipt endorsed as paid, shall be delivered to the borrowing taxpayer or person making the payment. In the event of default the conditional tax receipt shall be returned to the lending corporation at its option.

$\$ 97-c$. Surrender of conditional tax receipt and issue of tax bill. Upon the surrender to the municipal corporation of the conditional tax receipt evidencing the discharge of the obligation created by the loan contract in connection with which the said conditional tax receipt was issued, the municipal corporation shall issue in lieu thereof a receipted tax bill. Such receipted tax bill shall bear the date of the conditional tax receipt and no interest and/or penalty shall be charged to the taxpayer for the period intervening between the date of the issuance of said conditional tax receipt and the date of its surrender; but until such receipted tax bill shall be issued all penalties and/or interest imposed by the municipal corporation for tax default shall be added to the tax lien until the discharge of the obligation created by the loan contract in connection with which the said conditional tax receipt was issued, and such penalties and/or interest shall be cancelled and be deemed satisfied upon the discharge of such obligation provided such obligation is discharged prior to the disposition of the tax lien as provided in section ninety-seven-d of this article. If subsequent to the issuance of the conditional tax receipt and independently of the payment by the lending corporation to the municipal corporation of the taxes covered by the conditional tax receipt, payment of said taxes shall be made by any person directly to the municipality in order to obtain a receipted tax bill, the lending corporation shall forthwith be repaid by the municipal corporation from such payment the balance due to it on the loan contract and it shall thereupon surrender to the municipal corporation the conditional tax receipt.

§97-d. Tax sales. Notwithstanding the issuance of a conditional tax receipt as provided by this act, the procedure now provided for by law for the sale or offering for sale of tax liens or properties for non-payment of taxes shall in all cases remain unchanged as if the conditional tax receipt had not been issued, provided, however that such sale or offering for sale shall not be held before the expiration of one year from the date of the issuance of any conditional tax receipt, but must be held within three years from said date, nothwithstanding the provision of any general or special law or charter provision to the contrary. Prior to said sale or offer ag for sale however, the lending corporation shall be required to exhibit to the municipal authority having jurisdiction over the sale of tax liens or properties the conditional tax receipt showing payments made on account of the loan contract, if any, which payments shall be credited against the amount due for taxes against the property to be sold which credit shall be given as of the date of the conditional tax receipt. The municipal corporation receiving the proceeds of the tax sale shall forthwith pay out of said proceeds the amount due to the lending corporation on the loan contract in connection with which the conditional tax receipt was issued and the said conditional tax receipt shall be surrendered by the lending corporation upon receipt of said payment. - Until payment from the proceeds of the sale has been made to the lending corporation or a receipted tax bill has been issued in exchange for the conditional tax receipt the lending corporation or its assigns, shall have an interest in and lien upon the tax lien or properties to the extent of the unliquidated portion of its loan; and the municipal corporation shall hold such interest and lien for the account of the lending corporation subject to the provisions of this article.

$\S 2$. This act shall take effect immediately. 